\title{
Protestant Empire
}





\section{Protestant Empire}

\section{Religion and the Making of the British Atlantic World}

Carla Gardina Pestana

\section{$\overline{\text { PENN }}$}

University of Pennsylvania Press

Philadelphia 
Copyright (C) 2009 University of Pennsylvania Press

All rights reserved. Except for brief quotations used for purposes of review or scholarly citation, none of this book may be reproduced in any form by any means without written permission from the publisher.

Published by

University of Pennsylvania Press

Philadelphia, Pennsylvania I9IO4-4II2

Printed in the United States of America on acid-free paper

IO $9 \begin{array}{llllllll} & 8 & 7 & 6 & 4 & 3 & 2 & \text { I }\end{array}$

Library of Congress Cataloging-in-Publication Data

Pestana, Carla Gardina.

Protestant Empire : Religion and the Making of the British Atlantic World / Carla Gardina Pestana.

p. cm.

Includes bibliographical references (p. ) and index.

ISBN 978-0-8I22-4I5O-I (alk. paper)

I. Great Britain-Church history. 2. Great Britain-Colonies-Africa-Religion. 3. Great Britain-Colonies-America-Religion. I. Title.

$\mathrm{BR}_{757 . P} 472009$

270.0917I' 24I-dc22

2008042299 
To the memory of my father, Ray Gardina 
